\title{
Pengaruh Model Pembelajaran JINEMAM Terhadap Berpikir Kritis Siswa Biologi
}

\section{Farida Sri Wahyuni, Dwi Candra Setiawan*}

Pendidikan Biologi, IKIP Budi Utomo, J1. Simpang Arjuno No.I4B, Malang (65I19), JA-TIM, Indonesia

*Korespondensi penulis: dwicandrasetiawan@budiutomomalang.ac.id

\begin{tabular}{l}
\hline Informasi artikel \\
\hline Riwayat artikel: \\
Diterima I5 Oktober 2019 \\
Direvisi $\quad 02$ November 2019 \\
Dipublikasi 29 November 2019 \\
\hline Kata kunci: \\
JINEMAM, berpikir kritis, \\
pemberdayaan, siswa biologi
\end{tabular}

pemberdayaan, siswa biologi
Faktor penentu keberhasilan pembentukan kemampuan berpikir kritis siswa adalah dengan menggunakan model pembelajaran yang tepat. Salah satunya adalah model pembelajaran JINEMAM. Penelitian ini bertujuan untuk menjelaskan pengaruh model pembelajaran JINEMAM terhadap berpikir kritis siswa. Penelitian ini menggunakan metode quasi eksperiment dengan pretest posttest nonequivalent control group design. Populasi penelitian yaitu siswa SMAS Diponegoro Tumpang Kabupaten Malang. Sampel penelitian yaitu siswa kelas XI IPAI sebagai kelas eksperimen sejumlah 23 siswa dan XI IPA2 sebagai kelas kontrol sejumlah 20 siswa. Instrumen tes berupa tes essay dan di uji reabilitas dan validitas sebelum digunakan. Data diperoleh dari hasil pretest posttest kedua kelas. Uji ANAKOVA digunakan sebagai uji hipotesis dengan taraf signifikansi 0,05 melalui aplikasi SPSS. Hasil penelitian menunjukkan bahwa nilai signifikansi $0,00<0,05$, sehingga menunjukkan bahwa model pembelajaran JINEMAM berpengaruh terhadap berpikir kritis siswa biologi. Dengan demikian, model pembelajaran JINEMAM memiliki potensi dalam memberdayakan berpikir kritis siswa.

\section{Keywords: \\ JINEMAM, critical thinking,} empowerment, biology students

\section{ABSTRACT}

The effect of JINEMAM learning model on biology students critical thinking Skills. The critical success factor in the formation of students' critical thinking skills is to use an appropriate learning model. One of learning model is the JINEMAM learning model. This study aims to explain the effect of JINEMAM's learning model on students' critical thinking. This study uses a quasi experiment method with pretest posttest nonequivalent control group design. The population of the research was Diponegoro Tumpang High School students, Malang regency. The samples were students of class XI IPAI as an experimental class of 23 people and XI IPA2 as a control class of 20 people. The instrument used essay test is tested for reliability and validity before being used. The data is taken from the results of the pretest-posttest of the two classes. Hypothesis testing using ANACOVA with a level of significance 0.05 through the application of SPSS. The results showed that the significance value $0.00<$ 0.05 , thus indicating that the JINEMAM learning model influences students' critical thinking skills. Thus, the JINEMAM learning model has the potential to empower students 'critical thinking skills.

(C) 2019 Wahyuni \& Setiawan This is an open access article under the CC-BY-SA license

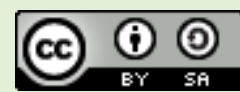

Sitasi: Wahyuni, F.S., \& Setiawan, D.C. (2019). Pengaruh model pembelajaran jinemam terhadap berpikir kritis siswa biologi. JPBIO (Jurnal Pendidikan Biologi), 4 (2), 60-66. DOI: 10.31932/jpbio.v4i2.494 


\section{PENDAHULUAN}

Usaha yang dilakukan oleh seorang pendidik (guru) untuk membelajarkan siswanya agar berinteraksi dan mencari atau mendapatkan sumber belajar lain dalam rangka menggapai tujuan yang diiiginkan adalah tercapainya pembelajaran yang baik dan sesungguhnya adalah hakikat dari pembelajaran (Trianto, 2012). Pembelajaran interaktif sangat membantu siswa dalam belajar dan pembelajaran akan terjadi apabila siswa mau dan mampu untuk berpikir kritis. Kemampuan berpikir kritis sangat penting dimiliki siswa, karena dengan memiliki kemampuam berpikir kritis siswa dapat berpikir secara rasional dalam mengatasi permasalahan yang tengah dihadapi serta mencari dan mengembangkan alternatif pemecahan bagi permasalahan tersebut (Karim, 20I5). Oleh karena itu, proses pembelajaran yang ada harus mampu mendorong kemampuan berpikir kritis siswa (Bustami et al., 2018).

Namun pada kenyataannya proses belajar mengajar umumnya kurang mendorong pada pencapaian kemampuan berpikir kritis. Hasil observasi dan wawancara dengan guru di tempat penelitian diperoleh data bahwa kemampuan berpikir kritis memang kurang diberdayakan. Kemampuan siswa hanya dikembangkan dari aspek kognitif tingkat rendah saja, sehingga hal ini yang mendasari untuk dilakukan penelitian tentang pemberdayaan berpikir kritis siswa. Rendahnya tentang pemberdayaan berpikir kritis siswa juga diungkapkan oleh penelitian Sudin et al. (2018), Sukmaningtyas et al. (2018), dan Khalistyawati \& Muhyadi (2018). Hal yang sama diungkapkan oleh Nurmala et al. (2015) dan Dewi at al. (2018) yang juga menyebutkan bahwa masih rendahnya pemberdayaan berpikir kritis siswa dalam proses pembelajaran.

Faktor penyebab berpikir kritis siswa tidak dapat berkembang selama pendidikan, yang pertama adalah kurikulum. Umumnya, kurikulum dibuat dan disusun menggunakan target materi yang cukup luas sehingga guru lebih terfokus pada penyelesaian materi. Kedua, bahwa aktivitas pembelajaran di kelas yang selama ini dilakukan oleh guru tidak lain merupakan penyampaian informasi (metode ceramah), dimana peran guru menjadi lebih aktif dan dominan, sedangkan siswa cenderung pasif hanya melakukan kegiatan mendengarkan dan menyalin, serta sesekali siswa menjawab jika guru memberikan permasalahan (Bustami \& Corebima, 2017; Sukmaningtyas et al., 2018; Khalistyawati \& Muhyadi, 2018). Padahal, pelajaran biologi adalah pelajaran yang menuntut siswa untuk lebih perhatian, aktif dan berpikir kritis dalam pembelajaran. Dewi et al. (2018) yang menyatakan bahwa proses pembelajaran di Indonesia seharusnya dikembangkan dengan menuntut siswa lebih aktif sehingga kemampuan berpikir kritisnya semakin berkembang dalam memecahkan suatu masalah.

Upaya untuk mengatasi persoalan tersebut, dengan mengaplikasikan pendekatan cooperative learning. Pendekatan cooperative learning merupakan pembelajaran yang mengharuskan siswa agar bekerjasama, saling membantu dan melengkapi dalam menyelesaikan masalah yang diberikan oleh guru. Melalui strategi pembelajaran kooperatif siswa dapat belajar dari apa yang diberikan oleh guru dan juga dapat bertukar pikiran serta dapat belajar dengan teman. Pembelajaran kooperatif dapat memberikan dorongan siswa terhadap kemampuan berpikir kritis (Loes \& Pascarella, 2017; Changwong et al., 2018; Erdogan, 2019).

Faktor penentu keberhasilan dalam pembentukan kemampuan berpikir kritis siswa adalah dengan menggunakan metode atau model pembelajaran yang tepat. Diantara berbagai model pembelajaran yang dapat menfasilitasi untuk membentuk kemampuan berpikir kritis adalah model pembelajaran JINEMAM (Jigsaw, Examples Non Examples dan Make A Match). Dewasa ini banyak model-model pembelajaran yang telah dikemukakan oleh para ahli dan memiliki kelebihan dan kekurangannya masing-masing. Perpaduan beberapa model pembelajaran yang tepat dan dengan menggunakan teknik pembelajaran yang menarik dapat lebih memotivasi dalam belajar siswa. Oleh karena itu, perlu memadukan beberapa model pembelajaran yaitu Jigsaw, Examples Non Examples dan Make A Match yang disingkat menjadi JINEMAM.

Model pembelajaran JINEMAM merupakan hasil perpaduan dari ketiga model pembelajaran yang memiliki kelebihan atau keunggulan. Examples Non Examples merupakan model pembelajaran dimana dalam proses pembelajarannya menggunakan gambar sebagai penyampaian materi (Wardika et al., 20I4). Salah satu kelebihan dari Examples Non Examples adalah penggunaan gambar sebagai tugas siswa, sehingga siswa lebih kritis dalam menganalisis gambar (Asmayanti, 2017). Selanjutnya, model Jigsaw merupakan model pembelajaran kooperatif yang di dalamnya terdapat unsur kelompok asal dan kelompok ahli dalam proses diskusinya (Khalistyawati \& Muhyadi, 2018). Adanya tim asal dan tim ahli dalam menyelesaikan tugas atau permasalahan dapat meningkatkan kemampuan berpikir siswa (Beni et al., 2019). Palennari (20II) yang juga menyatakan bahwa adanya diskusi kelompok untuk membahas permasalahan yang sama akan membantu siswa untuk mengembangkan kemampuan berpikir mereka dengan menganalisa setiap pendapat dari masing-masing teman kelompoknya.

Model JINEMAM juga menggunakan gambar sebagai permasalahan dalam lembar siswa (LS) yang dianalisis oleh masing-masing tim ahli. Media gambar yang merupakan media visual akan membantu dalam

dol10.31932/jpbio.v4i2.494 Wahyuni \& Setiawan @iurnaljpbio@gmail.com


peningkatan kemampuan berpikir siswa karena siswa lebih tertarik dalam mengikuti proses pembelajaran. Terakhir, model JINEMAM menggunakan permainan mencari pasangan kartu soal dan kartu jawaban dalam tipe make a match juga dapat mendorong siswa untuk berpikir secara analitis melihat kecocokan suatu konsep dengan konsep yang lain (Deschuri et al., 2016).

Atas dasar keunggulan dari perpaduan ketiga model tersebut diharapkan model pembelajaran JINEMAM mampu memberdayakan kemampuan berpikir kritis siswa seperti hasil penelitian Setiawan \& Setiawan (2018) yang menjelaskan model JINEMAM mampu memberdayakan berpikir kritis mahasiswa IKIP Budi Utomo Malang. Berdasarkan latar belakang yang telah dipaparkan, maka perlu dilakukan penelitian dengan dengan melihat pengaruh model pembelajaran JINEMAM terhadap kemampuan berpikir kritis siswa SMAS Tumpang. Tujuan dari penelitian ini adalah untuk mengetahui pengaruh model JINEMAM terhadap berpikir kritis siswa.

\section{METODE PENELITIAN}

\section{Rancangan Penelitian}

Penelitian ini merupakan penelitian kuantitatif dengan menggunakan jenis penelitian quasi eksperiment dengan pretest posttest nonequivalent control group design. Quasi eksperiment atau eksperimen semu adalah penelitian yang tidak dapat memberikan kontrol secara penuh. Desain atau rancangan pretest-postest nonequivalent control group dapat dilihat pada Tabel I.

Tabel I. Pretest posttest nonequivalent control group design

\begin{tabular}{ccc}
\hline Pretest & Treatment & Posttest \\
\hline $\mathrm{O}_{1}$ & $\mathrm{x}$ & $\mathrm{O}_{2}$ \\
\hline $\mathrm{O}_{3}$ & - & $\mathrm{O}_{4}$ \\
\hline
\end{tabular}

Keterangan :

$\mathrm{O}_{\mathrm{I}} \quad$ : Pretest kelas eksperimen

$\mathrm{O}_{3} \quad$ : Pretest kelas kontrol

$\mathrm{O}_{2} \quad$ : Posttest kelas eksperimen

$\mathrm{O}_{4} \quad$ : Posttest kelas kontrol

$\mathrm{X} \quad$ : Perlakuan dengan model JINEMAM.

\section{Populasi dan Sampel Penelitian}

Populasi penelitian ialah seluruh siswa kelas XI SMAS Diponegoro Tumpang Kabupaten Malang. Teknik pengambilan sampel menggunakan metode cluster random sampling yaitu dengan memilih kelompok kelas yang mempunyai jumlah siswa tidak berbeda jauh antara kelas kontrol dengan kelas ekperimen. Kelas XI IPAI berjumlah siswa 23 sebagai kelas eksperimen dan XI IPA2 berjumlah 20 siswa sebagai kelas kontrol.

\section{Instrumen Penelitian}

Perangkat pembelajaran yang digunakan dalam penelitian ini ialah: silabus, rencana pelaksanaan pembelajaran (RPP), lembar siswa, dan perangkat tes berbentuk tes subyektif (essay) sebanyak I5 soal. Perangkat tes sebelum digunakan diujicoba untuk mengetahui nilai reabilitas dan validitas butir soal. Rubrik penilaian kemampuan berpikir kritis di gunakan untuk mengukur variabel terikat dan mengacu pada indikator berpikir kritis oleh Finken \& Ennis (1993).

\section{Prosedur Penelitian}

Data penelitian berupa data kuantitatif skor nilai dari rubrik berpikir kritis dengan tes essay. Data hasil penelitian dikumpulkan melalui pretest dan posttest yang dilakukan sebelum dan sesudah seluruh materi pada semester genap tanggal I9 Februari 2018 sampai dengan tanggal I9 April 2018 dengan 12 kali pertemuan pada materi sistem koordinasi dan sistem reproduksi manusia terhadap berpikir kritis siswa.

\section{Teknik Analisis Data}

Teknik analisis data yang digunakan berupa uji instrumen (uji reliabilitas dan validitas), uji prasyarat (uji normalitas dan homogenitas) dan uji hipotesis dengan teknik ANAKOVA. Pemilihan analisis ANAKOVA dikarenakan penggunaan kovariat bertujuan untuk mengurangi noise pada analisis data yang disebabkan oleh variabel lain selain variabel yang diteliti, sehingga harapannya pengaruh atau dampak dari variabel yang diteliti dapat terlihat dengan jelas (Trochim, 2006). Analisis data menggunakan program SPSS versi 22.

dol10.31932/jpbio.v412.494 Wahyuni \& Setiawan




\section{HASIL PENELITIAN}

Berdasarkan hasil analisis data, diperoleh data hasil uji reliabilitas dan uji validitas yang dapat ditunjukkan pada Tabel 2.

Tabel 2. Reliability statistics

\begin{tabular}{ccc}
\hline Cronbach's Alpha & Cronbach's Alpha Based on Standardized Items & Nof Items \\
\hline .597 & .555 & $\mathrm{I} 5$ \\
\hline
\end{tabular}

Berdasarkan hasil data yang diperoleh dari 15 soal yang telah diuji cobakan dengan responden sebanyak 37 siswa, Cronbach's Alpha = 0,597 maka soal dikatakan cukup reliabel karena 0,597 terletak pada $(0,60>\mathrm{x} \geq$ 0,4I). Selanjutnya, uji validitas memiliki ketentuan, soal dinyatakan valid jika thitung $>$ rtabel. Responden yang digunakan sebanyak 37 siswa dengan menggunakan $\alpha=0,05$ maka rtabel=0,2746. Hasil perhitungan uji validitas dengan menggunakan SPSS I6.0 dapat dilihat pada Tabel 3.

Tabel 3. Item-total statistic

\begin{tabular}{|c|c|c|c|c|c|}
\hline Nomor & $\begin{array}{l}\text { Scale Mean if } \\
\text { Item Deleted }\end{array}$ & $\begin{array}{l}\text { Scale Variance if } \\
\text { Item Deleted }\end{array}$ & $\begin{array}{l}\text { Corrected Item- } \\
\text { Total Correlation }\end{array}$ & $\begin{array}{c}\text { Squared } \\
\text { Multiple } \\
\text { Cortelation }\end{array}$ & $\begin{array}{l}\text { Cronbach's Alpha } \\
\text { if Item Deleted }\end{array}$ \\
\hline I & 15.97 & 44.027 & .324 & .552 & .563 \\
\hline 2 & 17.62 & 46.575 & .274 & .395 & .576 \\
\hline 3 & 17.08 & 46.632 & .065 & .569 & $.62 \mathrm{I}$ \\
\hline 4 & 16.49 & 45.090 & .240 & .472 & .579 \\
\hline 5 & 17.92 & $50.4 \mathrm{IO}$ & -.027 & .290 & $.6 \mathrm{I} 4$ \\
\hline 6 & 15.65 & $40.5 \mathrm{I} 2$ & .287 & .446 & .572 \\
\hline 7 & 16.05 & $46.94 \mathrm{I}$ & .254 & .367 & .579 \\
\hline 8 & I8.I4 & 51.509 & -.262 & .378 & .606 \\
\hline 9 & 16.86 & 44.065 & .443 & .427 & .550 \\
\hline 10 & 16.65 & 46.956 & .184 & .442 & .588 \\
\hline II & 17.22 & 4I.I74 & .456 & .513 & .535 \\
\hline 12 & 16.78 & 49.174 & .016 & .200 & .615 \\
\hline 13 & 17.62 & 41.575 & .515 & .557 & .530 \\
\hline 14 & 16.62 & 44.853 & .184 & .177 & $.59 \mathrm{I}$ \\
\hline 15 & 17.59 & 44.970 & .324 & $.50 \mathrm{I}$ & .566 \\
\hline
\end{tabular}

Berdasarkan hasil Tabel 3. dapat diamati pada kolom corrected item-total correlation butir soal yang tidak valid terdapat pada nomor 3, 4, 5, 7, 8, I0, I2 dan I4. Soal yang tidak valid akan direvisi sebelum dilakukan penelitian. Selanjutnya, hasil uji normalitas diketahui $\operatorname{Sig}(2$-tailed) $>\alpha$ atau 0,846 $>0,05$ jadi data berdistribusi normal. Hasil uji homogenitas menujukkan nilai Sig $>\alpha$ atau $0,465>0,05$, sehingga disimpulkan bahwa data diambil dari sampel yang homogen.

Tabel 4. Ringkasan ANAKOVA hasil penghitungan data kemampuan berpikir kritis

\begin{tabular}{lrrrrr}
\hline Source & $\begin{array}{r}\text { Type III Sum of } \\
\text { Squares }\end{array}$ & df & Mean Square & F & Sig. \\
\hline Corrected Model & I0423.9I4 & 2 & 5211.957 & 53.173 & .000 \\
\hline Intercept & 3443.360 & I & 3443.360 & 35.130 & .000 \\
\hline Kelas & 5754.737 & I & 5754.737 & $58.71 \mathrm{I}$ & .000 \\
\hline Error & 3920.737 & 40 & 98.018 & & \\
\hline Total & $576 \mathrm{I} 2.000$ & 43 & & & \\
\hline Corrected Total & I4344.65I & 42 & & & \\
\hline
\end{tabular}

a. $R$ Squared $=, 727$ (Adjusted $R$ Squared $=, 713)$ 
Hasil uji hipotesis dengan menggunakan SPSS pada Tabel 4 diketahui bahwa nilai signifikansi 0,000< 0,05 sehingga Ho ditolak. Disimpulkan bahwa JINEMAM berpengaruh secara signifikan terhadap kemampuan berpikir kritis siswa.

\section{PEMBAHASAN}

Hasil uji ANAKOVA menunjukkan bahwa model pembelajaran JINEMAM berpengaruh terhadap kemampuan berpikir kritis siswa, hal ini terlihat dari adanya perbedaan nilai yang sangat signifikan. Siswa yang mendapatkan pembelajaran dengan menggunakan model pembelajaran JINEMAM mendapat peningkatan nilai yang tinggi dibandingkan dengan siswa yang menggunakan metode konvensional dalam penyampaian materi pembelajaran. Hasil penelitian ini sejalan dengan penelitian yang dilakukan oleh Setiawan \& Setiawan (2018) bahwa model pembelajaran JINEMAM berpengaruh signifikan terhadap berpikir kritis siswa. Perbedaan ini terjadi karena JINEMAM adalah perpaduan dari ketiga model pembelajaran kooperatif yang memiliki sintak yang sangat mendukung dan saling melengkapi saat dipadukan.

Pembelajaran kooperatif adalah pembelajaran berkelompok yang menuntut siswa untuk saling berinteraksi, bekerja sama dalam memecahkan masalah atau tugas yang diberikan oleh guru, dalam pembelajaran berkelompok anggota kelompok terdiri dari berbagai macam tinggat kecerdasan atau kepintaran siswa (homogen) sehingga siswa yang kurang pintar dapat belajar kepada temannya yang lebih pintar. Pendapat ini juga sesuai dengan Setiawan et al. (2016) yang menyatakan interaksi sosial yang terjadi dalam kelompok dapat meningkatkan kemampuan berpikir anak karena anak yang merasa kurang pandai akan terbantu dan anak yang merasa pandai akan berusaha menjelaskan kepada temannya yang kurang pandai sehingga pemahamannya menjadi lebih mendalam. Sukmaningtyas et al. (2018) menjelaskan bahwa model kooperatif dirancang untuk mampu mengembangkan kemampuan akademik siswa mulai dari low order thinking sampai high order thinking. Melalui interaksi sosial yang seperti ini dapat menumbuhkan dan meningkatkan berpikir siswa.

Model pembelajaran JINEMAM terbukti mampu meningkatkan berpikir kritis siswa. Hal ini terbukti dari pertanyaan soal atau tugas berupa gambar yang harus dianalisis dan didiskusikan bersama oleh siswa di dalam lembar siswa (LS). Pemecahan masalah yang terdapat di LS dengan adanya tim ahli dapat segera terpecahkan karena siswa dapat berpikir bersama dan saling berdiskusi. Pertanyaan-pertanyaan yang ada di dalam LS memiliki tingkatan-tingkatan yang berbeda, artinya tidak hanya pertanyaan tingkat rendah akan tetapi LS didominasi oleh pertanyaan tinggat tinggi sehingga dapat memicu meningkatkan berpikir kritis siswa. Hal ini sejalan dengan Corebima (2008) yang menjelaskan melalui pertanyaan-pertanyaan akan memicu pola berpikir siswa, sehingga jika terus dilatih akan mampu meningkatkan berpikir kritis siswa.

Perpaduan model pembelajaran Jigsaw, Examples Non Examples dan Make A Match, untuk memadukan kelebihan atau keunggulan dari ketiga model pembelajaran tersebut mampu meningkatkan kemampuan berpikir kritis siswa. Langkah awal yaitu memadukan model pembelajara Jigsaw dan Examples Non Examples. Salah satu kelebihan dari Examples Non Examples adalah menggunakan gambar sebagai tugas siswa, sehingga siswa lebih kritis dalam menganalisis gambar (Asmayanti, 2017). Kelebihan dari Jigsaw dengan adanya tim asal dan tim ahli dalam menyelesaikan tugas atau permasalahan dapat meningkatkan kemampuan berpikir kreatif siswa (Pranata, 2013). Pada tahap inilah peneliti memadukan keunggulan dari kedua sintaks tersebut. Gambar digunakan sebagai permasalahan dalam lembar siswa (LS) yang dianalisis oleh masing-masing tim ahli, menganalisis gambar akan lebih memicu dalam menumbuhkan kemampuan berpikir kritis siswa.

Langkah selanjutnya, Make A Match dipadukan pada tahap akhir. Deschuri, et al. (2016) berpendapat bahwa salah satu keunggulan Make $A$ Match adalah siswa mampu belajar tentang suatu konsep maupun topik melalui kegiatan proses mencari pasangan serta dalam suasana yang menyenangkan. Mencari pasangan kartu soal dan kartu jawaban yang tepat dapat mendorong siswa untuk berpikir secara analitis melihat kecocokan suatu konsep dengan konsep yang lain. Setiawan \& Setiawan (2018) juga menyatakan bahwa proses mencocokan kartu soal dan kartu jawaban dengan tepat dan benar akan menuntut siswa untuk berpikir menemukan jawaban yang benar sehingga akan dapat melatih proses berpikir kritis siswa. Presentasi dari hasil kartu yang telah dicocokkan di depan kelas juga melatih keberanian siswa dan menguji sejauh mana pemahaman siswa sehingga dapat mengasah kemampuan berpikirnya. Presentasi dilakukan sekaligus dengan klarifikasi jika ada jawaban yang kurang benar atau salah, guru dapat membenarkan sehingga siswa dapat memperoleh pemahaman yang benar.

Berdasarkan uraian tersebut maka model pembelajaran JINEMAM mampu memberdayakan pola berpikir siswa sehingga siswa mampu menumbuhkan kemampuan berpikirnya. Keunggulan model pembelajaran JINEMAM yaitu dapat memberikan masalah, menyelesaikan masalah sekaligus mengevaluasi hasil pembelajaran. Perpaduan model pembelajaran Jigsaw, Examples Non Examples dan Make A Match ini akan lebih didapatkan hasil yang lebih baik dalam memberdayakan kemampuan berpikir kritis siswa.

dol10.31932/jpbio.v4i2.494 Wahyuni \& Setiawan @jurnalipbio@gmail.com




\section{SIMPULAN}

Berdasarkan hasil analisis data dan pembahasan dapat disimpulkan bahwa model pembelajaran JINEMAM (Jigsaw, Examples Non Examples dan Make A Match) berpengaruh terhadap kemampuan berpikir kritis siswa. Dengan demikian, model pembelajaran JINEMAM disarankan dapat diaplikasikan dalam pembelajaran, karena memiliki potensi untuk memberdayakan kemampuan berpikir kritis siswa, sehingga secara tidak langsung hasil belajar kognitif siswa dapat meningkat.

\section{REFERENSI}

Asmayanti, D. (2017). Penerapan model pembelajaran example dan nonexample untuk meningkatkan aktivitas belajar sejarah siswa kelas X SMA Al-Huda Jatiagung Lampung Selatan, (Tesis tidak diterbitkan), Program Pascasarjana Magister Pendidikan IPS Fakultas Keguruan dan Ilmu Pendidikan Universitas Bandar Lampung, Lampung.

Beni, B., Bustami, Y., \& Leliavia, L. (2019). Implementasi model pembelajaran kooperatif tipe JiRQA terhadap kemampuan berpikir kritis siswa pada materi pertumbuhan dan perkembangan tumbuhan. Edubiotik: Jurnal Pendidikan, Biologi dan Terapan, 4(I), 9-I5. DOI: I0.33503/ebio.v4i01.308

Bustami, Y., \& Corebima, A.D. (2017). The effect of jirqa learning strategy on critical thinking skills of multiethnic students in higher education, Indonesia. International Journal of Humanities Social Sciences and Education (IJHSSE), 4(3), I3-22. DOI: I0.2043I/2349-0381.0403003

Bustami, Y., Syafruddin, D., \& Afriani, R. (2018). The implementation of contextual learning to enhance biology students' critical thinking skills. Jutnal Pendidikan IPA Indonesia, 7(4), 45I-457. DOI: I0.I5294/jpii.v7i4.II72I

Changwong, K., Sukkamart, A., \& Sisan, B. (2018). Critical thinking skill development: Analysis of a new learning management model for Thai high schools. Journal of International Studies, II(2), 37-48. DOI: I0.14254/207I-8330.2018/II-2/3

Corebima, A.D. (2008). Dosen anak bangsa. Makalah Disajikan pada Pelatihan Pembelajaran Kooperatif TPS dan Jigsaw dengan Strategi Metakognitif Pada Dosen-dosen Biologi di SMAN Kota Pekanbaru. 5 Mei 2008.

Erdogan, F. (2019). Effect of cooperative learning supported by reflective thinking activities on students' critical thinking skills. Eurasian Journal of Educational Research, 20I9(80), 89-II2. DOI: I0.14689/ejer.2019.80.5

Deschuri, C., Kurnia, D., \& Gusrayani, D. (2016). Penerapan model kooperatif make a match dengan media kartu klop untuk meningkatkan hasil belajar siswa. Jurnal Pena Ilmiah, I(I); 36I-370. DOI: I0.23819/pi.vIiI.3042

Dewi, R., Ege B., \& Syafruddin, D. (2018). Pengaruh model pembelajaran kooperatif tipe cooperative, integrated, reading, and composition berbasis media peta konsep terhadap kemampuan berpikir kritis siswa pada materi sistem pencernaan manusia. JPBIO (Jurnal Pendidikan Biologi), 3(2), 3I-40. DOI: 10.31932/jpbio.v3i2.307

Finken, M., \& Ennis, R.H. (1993). Illions critical thinking essay test. Illinois Critical Thinking Project. Departemen of Educational Policy Studies University of Illinois. http://evolkov.net/critic.think/tests/IllCTEssayTestFinken-EnnisI2-I993LowR.pdf

Karim, N. (2015). Kemampuan berpikir kritis siswa dalam pembelajaran matematika dengan menggunakan model jucama di sekolah menengah pertama. Jurnal Pendidikan Matematika, 3(I), 92-104.

Khalistyawati, M., \& Muhyadi. (2018). Pengaruh model STAD dan jigsaw terhadap karakter kerja sama, kemampuan berpikir kritis, dan hasil belajar kognitif. Jurnal Pendidikan Karakter, 7(2), I87-205. DOI: I0.2I83I/jpk.v8i2.2I852

Loes, C.N., \& Pascarella, E.T. (2017). Collaborative Learning and Critical Thinking: Testing the Link. Journal of Higher Education, 88(5), 726-753. DOI: I0.1080/00221546.2017.129I257

Nurmala, R.S., Corebima, A.D., \& Ibrohim, I. (2015). Pengaruh strategi problem based learning dipadu jigsaw terhadap kemampuan berpikir kritis dan hasil belajar siswan kelas X SMA. Jurnal Pendidikan Sains, 3(3), I30-I36. DOI: 10.17977/jps.v3i3.8II0

Palennari, M. (20II). Potensi strategi PBL integrasi dengan pembelajaran kooperatif jigsaw dalam meningkatkan pemahaman konsep mahasiswa. Jurnal Ilmiah Pendidikan Biologi, Biologi Edukasi, 3(2), 26-33. http://jurnal.unsyiah.ac.id/JBE/article/view/466 
Pranata, A. (2013). Pengaruh model pembelajaran kooperatif tipe jigsaw terhadap hasil belajar ipa siswa pada konsep cahaya, (Skripsi tidak diterbitkan), Program Studi Pendidikan Guru Madrasah Ibtidaiyah Jurusan Kependidikan Islam Fakultas Ilmu Tarbiyah dan Keguruan Uin Syarif Hidayatullah, Jakarta.

Setiawan, D.C., Corebima, A.D., \& Zubaidah, S. (2016). Pengaruh strategi pembelajaran reciprocal teaching terhadap kemampuan berpikir kritis biologi siswa SMA Islam Al - Ma'arif Singosari Malang. BIODIK, 2(I). https://online-journal.unja.ac.id/biodik/article/view/3362

Setiawan, D.C., \& Setiawan, D. (2018). JINEMAM: Pengaruhnya terhadap kemampuan berpikir kritis mahasiswa IKIP Budi Utomo Malang. Makalah disajikan dalam Seminar Pendidikan Dan Pembelajaran 2 (Semdikjar 2). Universitas Nusantara PGRI Kediri 4 Agustus 2018.

Sudin, S., Duda, H.J., \& Supiandi, M.I. (2018). Pengaruh model reading questioning answering terhadap kemampuan berpikir kritis siswa pada pokok bahasan sistem pernapasan manusia. JPBIO (Jurnal Pendidikan Biologi), 3(I), I-8. DOI: I0.31932/jpbio.v3iI.260

Sukmaningtyas, B., Madang, K., \& Suratmi, S. (2018). Pengaruh model pembelajaran kooperatif tipe jigsaw terhadap berpikir tingkat tinggi ( higher order thinking skills ) kelas XI pada materi sistem pencernaan di SMA Negeri I Tanjung Raja. Jurnal Pembelajaran Biologi, 5(2), 67-74. DOI: 10.36706/fpbio.v5i2.7062

Trianto, T. (2012). Model pembelajaran terpadu. Jakarta: Bumi Aksara.

Trochim, W. (2006). The research methods knowledge base. New York: Cornell University.

Wardika, K., Sulastri, M., \& Dibia, K. (2014). Pengaruh model example non example terhadap hasil belajar IPA siswa kelas V SD Di Gugus III Kecamatan Tampaksiring. Jurnal Mimbar PGSD UNDIKSHA, 2(I), IIO. DOI: I0.23887/jipgsd.v2iI.309I 